\title{
ALOE IRAFENSIS AN ENDEMIC PLANT OF YEMEN: PHYTOCHEMICAL SCREENING, ANTIBACTERIAL, ANTIOXIDANT, AND WOUND HEALING ACTIVITIES
}

\author{
BUSHRA ABDULKARIM MOHARRAM ${ }^{1 *}$, HASSAN M. AL-MAHBASHI ${ }^{2}$, TAREQ AL-MAQTARI ${ }^{3,4}$, RIYADH SAIF-ALI ${ }^{5}$, \\ AMIN A. AL-DOAISS
}

${ }^{1}$ Department of Pharmacognosy, Faculty of Pharmacy, Sana'a University, Sana'a, Yemen. ${ }^{2}$ Department of Forensic Medicine and Clinical Toxicology, Faculty of Medicine, Sana`a University, Sana'a, Yemen. ${ }^{3}$ Department of Pharmacology, Faculty of Pharmacy, Sana'a University, Sana'a, Yemen. ${ }^{4}$ Department of Pharmacology, Faculty of pharmacy, International University for Science and Technology, Daraa, Syria.

${ }^{5}$ Department of Biochemistry and Molecular Biology, Faculty of Medicine, Sana'a University, Sana'a, Yemen. ${ }^{6}$ Department of Anatomy and Histology, Faculty of Medicine, Sana'a University, Sana'a, Yemen.

Received: 17 April 2021, Revised and Accepted: 02 September 2021

ABSTRACT

Objectives: The objectives of the study were to determine the phytochemical constituents and to assess the antibacterial, antioxidant, and woundhealing properties of the methanol extracts of Aloe irafensis.

Methods: Methanol extracts of $A$. irafensis's latex, gel, and green skin were screened for their phytochemical constituents. All three extracts were investigated regarding their antibacterial potential using disc diffusion and microdilution assays, and their antioxidant activity using 2,2-diphenyl-1picrylhydrazyl free-radical scavenging assay. Histological analyses of wound healing areas were performed following the administration of the latex extract in male albino rats.

Results: The methanol extracts of $A$. irafensis revealed the presence of carbohydrates, steroids, phenols, tannins, and anthrones. The latex extract showed greater inhibition zones against Staphylococcus aureus and Pseudomonas aeruginosa (24 and 17 mm, respectively) with minimum inhibitory concentration values of 1.25 and $2.50 \mathrm{mg} / \mathrm{ml}$, respectively. The latex extract showed the highest antioxidant activity (IC ${ }_{50}$ of $65.54 \mu \mathrm{g} / \mathrm{ml}$ ), followed by green skin extract $\left(\mathrm{IC}_{50}\right.$ of $89.48 \mu \mathrm{g} / \mathrm{ml}$ ). The latex extract significantly accelerated the rate of wound healing in rats (p<0.01), compared to the reference control fucidin ointment. Histological findings showed remarkably less scar width at wound closure site in the latex extract-treated wounds. Granulation tissue contained fewer inflammatory cells and more fibroblasts in wounds treated with the latex extract compared to those treated with the vehicle.

Conclusion: A. irafensis latex extract is a potential source of bioactive compounds that can be exploited for antioxidant, antibacterial, and wound healing purposes.

Keywords: Aloe irafensis, Phytochemical, Antioxidant, Antibacterial, Wound Healing.

(C) 2021 The Authors. Published by Innovare Academic Sciences Pvt Ltd. This is an open access article under the CC BY license (http://creativecommons.org/ licenses/by/4.0/) DOI: http://dx.doi.org/10.22159/ajpcr.2021v14i10.41832. Journal homepage: https://innovareacademics.in/journals/index.php/ajpcr

\section{INTRODUCTION}

Aloe (family Alliaceae) is a genus of about 500 species of flowering succulent plants [1]. They are commonly found in Southern Africa and on the eastern side of the continent. Many other species are found in the Arabian Peninsula and Madagascar [2]. There are about 33 Aloe species found in Yemen, 17 of which are considered endemic [3]. Aloe irafensis is one of the Aloe species endemic to Yemen, particularly in the city of Taiz where it is found in many parts of the city [3].

Several previous studies have shown that Aloe vera, a well-known Aloe species, possesses various biological activities including anticancer, hypoglycemic, hepatoprotective, gastroprotective, antibacterial, and antiviral activities [4-8]. The medicinal properties of $A$. vera are attributed to the presence of certain chemical components, such as anthraquinones, phytosterols, carbohydrates, chromes, enzymes, vitamins, amino acids, and proteins [9].

A. irafensis is traditionally used by locals in Yemen to speed healing wounds, to treat conjunctivitis, and as a laxative, among others. However, there is a significant shortage of data regarding A. irafensis, unlike its closely related species $A$. vera. Therefore, this study was undertaken to screen extracts of different parts of $A$. irafensis, regarding their phytochemical composition, as wells as their antibacterial, antioxidant, and wound-healing properties.

\section{METHODS}

Chemicals, reagents and drugs

Methanol (99.8\%; Scharlae, Spain), ethyl acetate (HiMedia, India), formic acid (Fluka, Switzerland), glacial acetic acid (WinLab, UK), chloroform (Sigma, Germany), diethyl ether (Scharlau, Spain), toluene (Scharlau, Spain), methanol (High-performance liquid chromatography (HPLC) grade) (Sigma, MO, USA), acetonitrile (HPLC grade) (Scharlau, Spain), and phosphoric acid (Scharlau, Spain) were used in plant extraction and chemical testing. Tween 80 (Uni-Chem, Beograd) and dimethyl sulfoxide (DMSO; Scharlae, Spain) were used as suspending agents. Formalin was purchased from BDH Chemicals, UK. The reagent 2,2-diphenyl1-picrylhydrazyl (DPPH) was purchased from Sigma-Aldrich, (USA). Ceftriaxone $1 \mathrm{~g}$ (Cipla, India), gentamicin $(80 \mathrm{mg} / 2 \mathrm{~mL}$; Alexandria CO, Egypt), and Vitamin C (Sigma, MO, USA) were used as standard drugs. Human blood agar (HuBA; Rapid labs, UK) and Mueller-Hinton agar (MHA; Scharlau, Spain) were used in the antimicrobial assay. Antibiotic discs, ceftriaxone $(30 \mu \mathrm{g})$, aztreonam $(30 \mu \mathrm{g})$, and gentamicin $(120 \mu \mathrm{g})$ were obtained from Oxide, England. Fusidic ointment 2\% (Fucidin ${ }^{\circledR}$, LEO Pharma, Ireland), thiopental ( $40 \mathrm{mg} / \mathrm{kg}$; Rotexmedica, Germany), and ketoprofen (Ketofan ${ }^{\circledast}$, Egypt) were used in wound healing assays.

\section{Plant materials}

The leaves of $A$. irafensis were collected from Taiz, Yemen in January of 2016. The plant was identified and confirmed by Dr. Abdul Wali Al 
Khulaidi, Public Authority for Research and Agricultural Extension, Dhamar city, Yemen. The voucher specimen of the plant was deposited in the Pharmacognosy Department, Faculty of Pharmacy, Sana'a University with a voucher number of Air1 2016.

\section{Preparation of the methanol extracts}

Preparation of $A$. irafensis extracts were carried out as previously described [10]. Briefly, the latex was collected from leaves after cutting the fresh leaves and drying them at room temperature for 2 days. The gel was also obtained from the cut leaves while the green skin of leaves was air-dried for 1 week. The three obtained plant parts (gel, latex, and green skin) were extracted with $99.8 \%$ methanol, filtered, and dried using a rotary evaporator. The percentage of yield for each extract was calculated based on dry weights. Yields were $0.03 \%$ for the gel, $80.94 \%$ for the latex, and $15.9 \%$ for the green skin. The dried extracts were then stored in desiccators for subsequent phytochemical screening and biological activity assessment.

\section{Experimental animals}

Adult male albino rats ( $n=30)$, weighing 200-250 g, were obtained from the animal house of the Faculty of Science, Sana'a University. The animals were housed in polypropylene cages maintained under standard conditions (12-h light-dark cycle cycle; $25 \pm 3^{\circ} \mathrm{C}$; $35-60 \%$ humidity) with strict hygienic conditions. Animals were provided standard chow and water accessible ad libitum. The rats were acclimatized to the laboratory conditions for at least $48 \mathrm{~h}$ before experimentation. All animal experiments were approved by the Institutional Ethical Committee, Faculty of Medicine and Health Sciences, Sana'a University, (02/FPhSana'a/2016).

\section{Phytochemical screening and fingerprinting}

Chemical tests were performed according to previous studies $[10,11]$ to identify alkaloids, carbohydrates, fixed oils, fats, steroids, anthraquinones, phenolic compounds, tannins, proteins, saponins, gum, and mucilage.

Components and their retention factor (Rf) values for A. irafensis extracts were identified using thin-layer chromatography (TLC) as per the conventional one-dimensional ascending method using 60 F254, $20 \mathrm{~cm} \times 20 \mathrm{~cm}$ silica gel sheets (Merck, Germany). TLC was performed as described previously $[12,13]$.

HPLC analysis was used to look at the chemical profiling of $A$. irafensis latex extract. The method was performed as described elsewhere [14] with few modification. The HPLC/ultraviolet (UV)-visible system consisted of a Shimadzu HPLC system comprised of a pump (LC 10AD vp, Shimadzu, Japan), a manual injector (7725i, USA), a UV-visible detector (SPD-10A vp, Shimadzu, Japan) and a degasser (DGU-14A, Shimadzu, Japan). A shim-pack CLC-ODS (M) C18 reversed-phase column (5 $\mu \mathrm{m}, 4.6 \times 250 \mathrm{~mm}$, Shimadzu, Japan) was employed, at ambient temperature. Separation was done using acetonitrile (A) and $0.1 \%$ aqueous phosphoric acid (B) with a gradient elution of $24 \% \mathrm{~A}$ at $0-12 \mathrm{~min}, 24-50 \% \mathrm{~A}$ at $12-22 \mathrm{~min}, 50-24 \% \mathrm{~A}$ at $22-40 \mathrm{~min}$, and $24 \% \mathrm{~A}$ at $40-50 \mathrm{~min}$. The flow rate was $1.0 \mathrm{ml} / \mathrm{min}$ and the separation was monitored by measuring UV absorbance at $254 \mathrm{~nm}$. The injection volume was $20 \mu \mathrm{l}$ of $1 \mathrm{mg} / \mathrm{ml}$ methanol extract.

\section{Antibacterial activity}

Test microorganisms

The antibacterial activity of $A$. irafensis's extracts was assessed against three local bacterial isolates, namely: Gram-positive Staphylococcus aureus and Gram-negative Pseudomonas aeruginosa and Escherichia coli. The bacteria were sub-cultured on $\mathrm{HuBA}$ at $35^{\circ} \mathrm{C}$ for $24 \mathrm{~h}$. The bacteria used were identified and obtained from the Microbiology by the Microbiology Department of Yemen Lab laboratory, Sana'a, Yemen.

\section{Antibacterial assays}

The antibacterial activity was performed using disc diffusion and broth microdilution assays. The disc diffusion method was performed as described previously [13].
Broth microdilution assay was performed according to the method of National Committee for Clinical Laboratory Standard [15] with few modifications [13]. The assay was done only for the extracts that exhibited an inhibition zone (IZ) greater than $15 \mathrm{~mm}$. The antibacterial activity was considered "strong" if minimum inhibitory concentration (MIC) $<1.00 \mathrm{mg} / \mathrm{mL}$, "moderate" if $1.00 \leq \mathrm{MIC} \leq 4.9 \mathrm{mg} / \mathrm{mL}$, and "weak" if $\mathrm{MIC} \geq 5.00 \mathrm{mg} / \mathrm{mL}$ [16].

Minimum bactericidal concentration (MBC) was determined by adding $20 \mu \mathrm{L}$ of broth taken from microtiter plate wells (used for determining MICs) which did not show visible bacterial growth and the broth was inoculated in the MHA medium in triplicates and then incubated for $24 \mathrm{~h}$ at $35^{\circ} \mathrm{C}$.

\section{Antioxidant activity}

The antioxidant activity of $A$. irafensis extracts was evaluated according to a previous work [13].

\section{Wound-healing activity}

The wound healing activity of the latex extract was assessed according to Moharram et al. [10]. Rats were weighed before the surgical procedure and anesthetized prior and during creation of wounds using $40 \mathrm{mg} /$ $\mathrm{kg}$ intraperitoneal thiopental. Subcutaneous $5 \mathrm{mg} / \mathrm{kg}$ ketoprofen (an analgesic) was injected into all animals right before surgical operation and then every $24 \mathrm{~h}$ afterwards for 2 consecutive days. The dorsal fur of the animals was shaved by an electrical shaver and swabbed with $70 \%$ alcohol. An area of uniform wound of $4 \mathrm{~cm}^{2}$ in length and $0.2 \mathrm{~cm}$ in depth was created at the nape of the dorsal neck of all rats with the aid of a square seal. The wounds made involved the lower subcutaneous tissue.

Rats were randomly divided into five groups of six rats each. Group 1 was untreated (negative control). Group 2 was topically dressed at the wound site with $0.2 \mathrm{ml}$ gum acacia (vehicle) twice a day for 14 days. Groups 3 and 4 were topically dressed with $0.2 \mathrm{ml} 100$ or $200 \mathrm{mg} / \mathrm{ml}$ (for Group 3 and Group 4, respectively) of the A. irafensis latex extract while Group 5 was dressed with $0.2 \mathrm{ml} 2 \%$ fusidic acid ointment and served as a positive control.

Each rat was then housed in an individual cage and the contraction of wound area was measured manually in square centimeters. The wound closure area was assessed by recording the wound area at days 0,7 , and 14 post-wounding using a transparent paper and a permanent marker as prescribed elsewhere [17]. The wound areas were measured using a graph paper.

The percentage of wound closure was calculated using the following equation:

Wound closure $(\%)=1-\frac{\mathrm{Ad}}{\mathrm{A} 0} \times 100$

A0 is the wound area at day 0 and Ad is the wound area on the corresponding day.

\section{Histopathological studies}

Tissue specimens were excised from healed cutaneous tissues obtained at day 14 post-operation from each rat. The excised tissue was preserved in neutral buffered formalin $(10 \%)$ at $4^{\circ} \mathrm{C}$. The tissue was then dehydrated in graded ethanol, cleared in xylene, embedded in paraffin, and blocked out. Then, $5 \mu \mathrm{m}$-thick sections of the tissues were mounted on glass slides. After dewaxing the sample, it was rehydrated in distilled water and stained with hematoxylin and eosin according to Suvarna et al. [18]. The prepared slides were examined under a compound microscope equipped with a digital camera to check the degree of re-epithelization, granulation tissue formation, and collagen deposition/organization.

\section{Statistical analysis}

Data were analyzed using Statistical Package for the Social Sciences (SPSS v. 11.5). Each sample was measured in triplicates, and the results 
were presented as means plus or minus standard deviations. Wound healing was calculated as a percentage of initial wound areas. Paired t-test was used to test the significance of differences between every two groups. Significance level was set at $<0.05$.

\section{RESULTS}

Phytochemical screening

Chemical and TLC testing of $A$. irafensis latex, gel and green skin extracts showed the presence of various bioactive components including carbohydrates, steroids, phenols, tannins, and anthrones. The chemical components of each extract, $\mathrm{Rf}$ values and the solvent systems used are presented in Table 1. TLC results indicated the presence of anthrones as evidenced by appearance of yellow spots in the $\mathrm{KOH}$-treated TLC plates containing latex (Rf. values $0.22,0.34$, and 0.45 ), gel (Rf. values $0.22,0.32$, and 0.45 ), and green skin (Rf. values 0.34 and 0.45 ) extracts under visible and UV light (UV wavelength $=365 \mathrm{~nm}$ ) (Fig. 1a and $\mathrm{b}$, respectively). However, coumarins were found only in the green skin extract as evidenced by the appearance of two light blue spots (Rf. values $0.13,0.14$ ) (Fig. 1c) under UV light (wavelength $365 \mathrm{~nm}$ ) induced by spraying the plates with $10 \%$ alcoholic $\mathrm{KOH}$. Furthermore, bitter components were found in the latex and green skin extracts as indicated by the appearance of one $\mathrm{KOH}$-induced colored spot for each extract $(\mathrm{Rf} .=0.38)$ under visible and UV-365 light.

HPLC analysis of A. irafensis latex extract showed the appearance of six major peaks and various minor others (Fig. 2). The major peaks appeared at retention times of 3.53, 9.18, 10.96, 13.52, 21.69, and $21.89 \mathrm{~min}$.

\section{Antibacterial activity}

The latex extract of $A$. irafensis showed strong antibacterial activity against $S$. aureus and $P$. aeruginosa with inhibition zones (IZs) of 24 and $17 \mathrm{~mm}$, respectively (Table 2). In addition, E. coli exhibited moderate sensitivity only to the latex extract (IZ $=10 \mathrm{~mm}$ ). MICs were determined only for the latex extracts that showed an IZ of greater than $15 \mathrm{~mm}$. The results indicated that the latex extract had MIC values of 1.25 and $2.5 \mathrm{mg} / \mathrm{ml}$ against $S$. aureus and P. aeruginosa, while MBCs values were 2.5 and $5.0 \mathrm{mg} / \mathrm{ml}$, respectively (Table 2 ).

\section{Antioxidant activity}

The three extracts of $A$. irafensis showed significant antioxidant activity (Fig. 3). The latex extract exhibited the highest antioxidant activity $\left(\mathrm{IC}_{50}\right.$ value of $65.54 \mu \mathrm{g} / \mathrm{ml}$ ) followed by the green skin extract $\left(\mathrm{IC}_{50}\right.$ value of $89.48 \mu \mathrm{g} / \mathrm{ml}$ )

\section{Wound-healing activity}

Wound closure area of wounds (in $\mathrm{cm}^{2}$ ) for the different animal groups was measured on days 0,7 , and 14 after wounding (Table 3, Fig. 4). Both concentrations ( 100 and $200 \mathrm{mg} / \mathrm{ml})$ of $A$. irafensis latex extract resulted in significant $(\mathrm{p}<0.01$ and $\mathrm{p}<0.001)$ wound healing on day 7 (1.6 and $0.93 \mathrm{~cm}^{2}$, respectively) and day $14\left(0.03\right.$ and $0.01 \mathrm{~cm}^{2}$, respectively) of inducing injury to rats' dorsal necks, compared to untreated and vehicle (gum acacia-treated) groups. Interestingly, on days 7 and 14 posttreatment, the $200 \mathrm{mg} / \mathrm{ml}$ latex extract of $A$. irafensis exhibited more reduction in wound area (0.93 and $0.01 \mathrm{~cm}^{2}$, respectively) compared to the reduction induced by fusidic acid ointment, a reference drug $(1.68$ and $0.44 \mathrm{~cm}^{2}$, respectively).

Histopathological examination of newly formed scars after 14 days after wounding is shown in Fig. 5. Histology of the wounds treated with the latex extract and fusidic acid ointment were associated with significantly less scar width compared to that induced by the vehicle. In addition, the wound of latex-treated group was partially to completely covered by newly formed epidermis and dermis layers. The extracellular matrix was also rich in newly-formed collagen fibers indicating rapid and progressive physiological wound healing in animals treated with the latex extract. Furthermore, the latex extract-treated group exhibited more proliferating blood capillaries (indicating enhanced angiogenesis) and dense collagen fibers in the granulation tissue of the wounded area
Table 1: TLC Investigation of methanol extracts of $A$. irafensis

\begin{tabular}{lllll}
\hline Constituent & Solvent system & Part & $\begin{array}{l}\text { NO. } \\
\text { spots }\end{array}$ & Rf values \\
\hline Anthraglycosid & Ethyl acetate: & Latex & 3 & 0.22 \\
(anthrones) & methanol: water & & & 0.32 \\
& $(100: 13.5: 10)$ & Gel & 3 & 0.45 \\
& & & & 0.22 \\
& & & & 0.32 \\
& & G. skin & 2 & 0.45 \\
& & & & 0.45 \\
Bitter & Ethyl acetate: & latex & 1 & 0.38 \\
principles & methanol: water & Gel & - & - \\
& (100:13.5:10) & G. skin & 1 & 0.38 \\
Alkaloids & Ethyl acetate: & Latex & - & - \\
& methanol: water & Gel & - & - \\
Flavonoids & (100:13.5:10) & G. skin & - & - \\
& Ethyl acetate: & latex & - & - \\
& formic acid: glacial & Gel & - & - \\
& acetic acid: water & Green & - & - \\
Saponins & (100:11:11:26) & skin & & \\
& Chloroform: glacial & latex & - & - \\
& acetic acid: methanol: & Gel & - & - \\
& water (64:32:12:8) & G. skin & - & - \\
Coumarins & Diethyl ether: toluene & latex & - & - \\
& (1:1) & Gel & - & - \\
& & G. skin & 2 & 0.13 \\
& & & & 0.14 \\
\hline
\end{tabular}

- = not detected, G. skin=green skin. A. irafensis: Aloe irafensis, Rf: Retention factor, TLC: Thin-layer chromatography

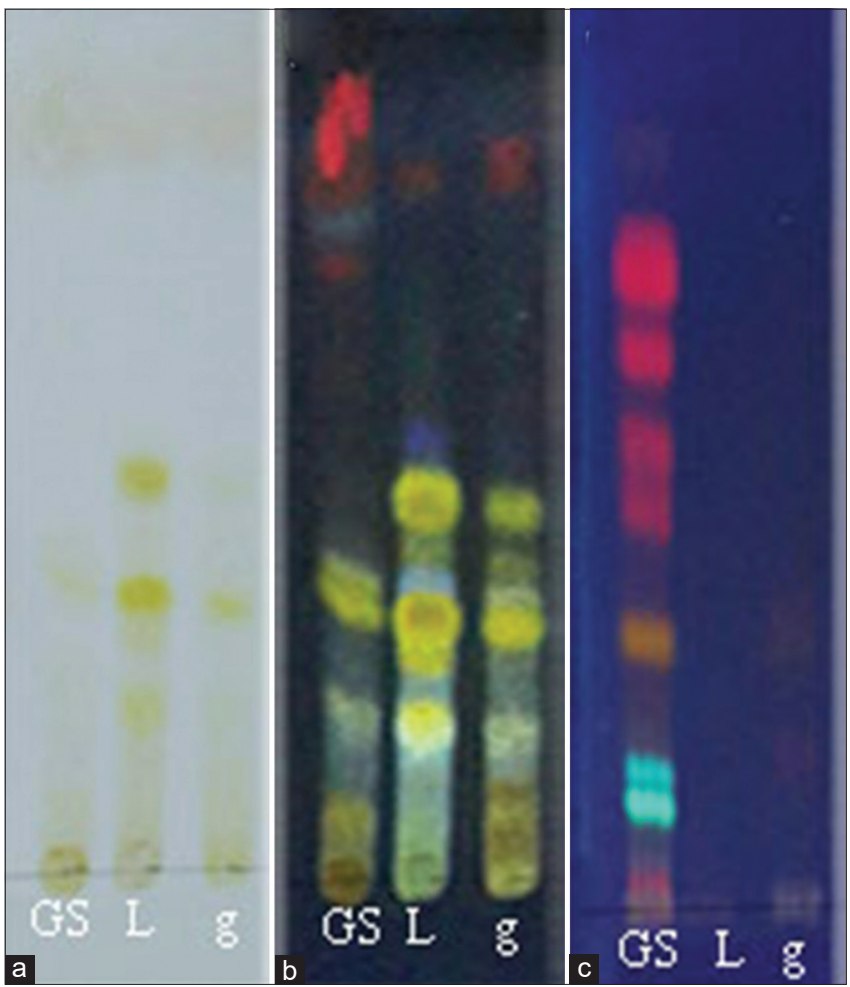

Fig. 1: Thin-layer chromatography plates of Aloe irafensis extracts (a-c). GS=green skin, L= latex, g= gel of $A$. irafensis, (a) TLC plate of anthraglycosides in visible light after spraying with $10 \%$ alcoholic KOH. (b) TLC plate of anthraglycosides in $365 \mathrm{~nm}$ after spraying with $10 \%$ alcoholic $\mathrm{KOH}$. (c) TLC plate of coumarins in ultraviolet $365 \mathrm{~nm}$ light

with almost complete absence of macrophages or edema compared to the vehicle group (Fig. 6). Histological evaluation revealed increased 
Table 2: IZ, MIC, MBCs of $A$. irafensis methanol extracts

\begin{tabular}{|c|c|c|c|c|c|}
\hline \multirow[t]{2}{*}{ Samples } & \multicolumn{3}{|l|}{ IZ (mm) } & \multicolumn{2}{|l|}{ MIC (MBC) in mg/ml } \\
\hline & S. aureus & E. coli & P. aeruginosa & S. aureus & P. aeruginosa \\
\hline Latex & $24.5 \pm 1.5$ & $10.0 \pm 0.0$ & $17.0 \pm 0.0$ & $1.25 \pm 0.0(2.5 \pm 0.0)$ & $2.5 \pm 0.0(5.0 \pm 0.0)$ \\
\hline G. Skin & $12.5 \pm 0.5$ & - & $11.5 \pm 0.5$ & nd & nd \\
\hline CRO $30 \mu \mathrm{g}$ & $20.0 \pm 0.0$ & nd & nd & nd & nd \\
\hline АТМ $30 \mu \mathrm{g}$ & nd & $35.0 \pm 0.0$ & nd & nd & nd \\
\hline CN $120 \mu \mathrm{g}$ & nd & $\mathrm{Nd}$ & $27.0 \pm 0.0$ & nd & nd \\
\hline Ceftriaxone & nd & nd & nd & $1.0 \pm 0.0$ & $\mathrm{Nd}$ \\
\hline Gentamicin & nd & nd & nd & nd & $5 \pm 0.0$ \\
\hline
\end{tabular}

Each value is the mean of three triplicates $\pm \mathrm{SD}$ (standard deviation). $\mathrm{CRO}=$ Ceftriaxone, $\mathrm{ATM}=$ Aztreonam, $\mathrm{CN}=\mathrm{Gentamicin},-=$ no activity, $(+\mathrm{ve})=$ positive control, nd = not determined. A. irafensis: Aloe irafensis, S. aureus: Staphylococcus aureus, P. aeruginosa: Pseudomonas aeruginosa, MIC: Minimum inhibitory concentration, E. coli: Escherichia coli, MBC: Minimum bactericidal concentration, IZ: Inhibition zone

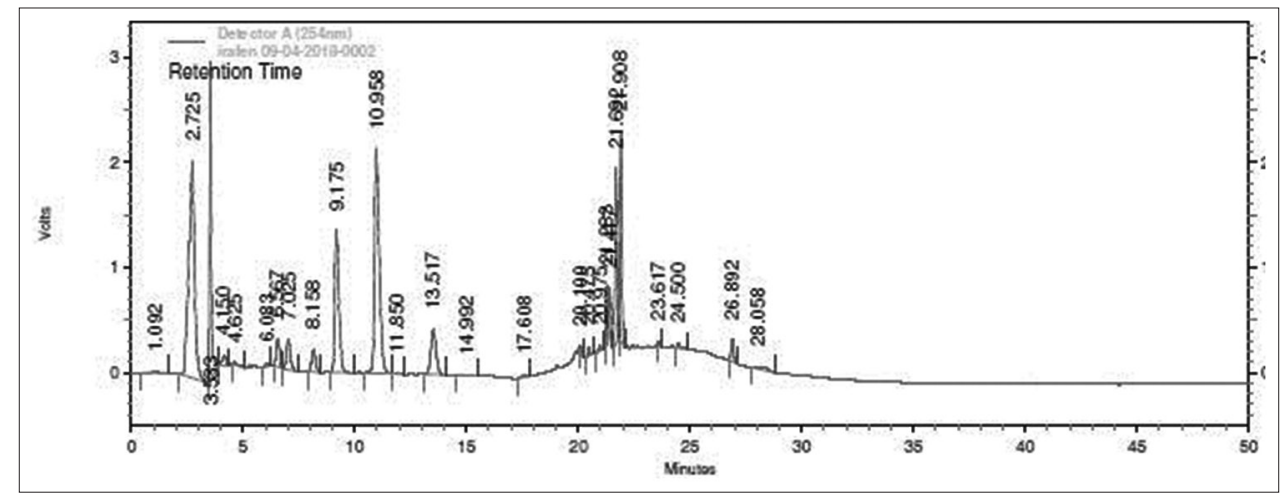

Fig. 2: High-performance liquid chromatography of Aloe irafensis latex extract at $254 \mathrm{~nm}$ absorbance using acetonitrile as solvent

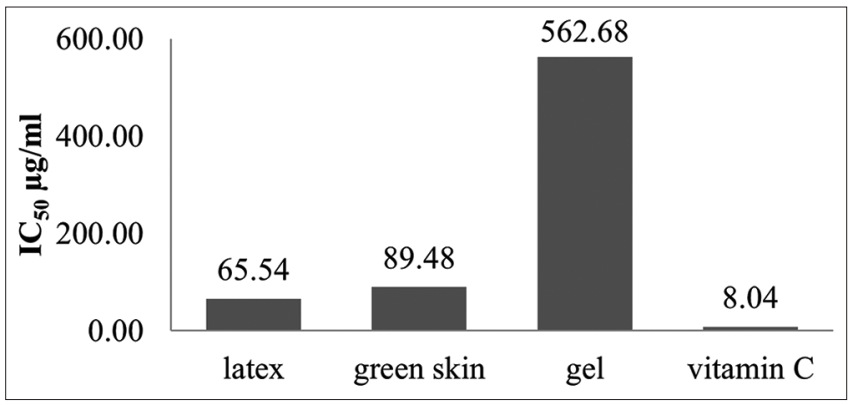

Fig. 3: $\mathrm{IC}_{50}$ values $(\mu \mathrm{g} / \mathrm{mL})$ of the methanol extracts of latex, green skin, and gel of Aloe irafensis and Vitamin C

cellular infiltration, collagen deposition, and re-epithelialization in the treated and the positive control groups but not in the vehicle-treated animals.

\section{DISCUSSION}

Several studies evaluated the biological activity, phytochemical screening, and clinical importance of various Aloe species. However, A. irafensis which is endemic to Yemen and traditionally used for antibacterial and wound healing, has not yet been well investigated. In this study, the chemical screening of $A$. irafensis indicated that the latex, gel, and green skin extracts contained carbohydrates, steroids, phenols, tannins, and anthrones which are commonly found in several Aloe species $[6,19]$.

Due to the development of antibiotic resistance, the present study endeavored to investigate the antibacterial potential of $A$. irafensis against clinically isolated bacterial pathogens including $S$. aureus and $P$. aeruginosa and E. coli. Among the plant extracts, the latex extract exhibited the highest antibacterial results against $S$. aureus and $P$. aeruginosa (bactericidal effect). The activity was shown to be comparable to that of the conventional antibiotics ceftriaxone and gentamicin. These results are in accordance with a recent study which reported that $A$. inermis latex extract showed strong antibacterial activity against $S$. aureus and P. aeruginosa [10]. Compounds such as alkaloids, tannins, flavonoids, anthraquinones, tannins as well as saponins were responsible for the antimicrobial activity of $A$. vera [20-22]. The exhibited antibacteral activity may also be due to a synergistic action exerted by multiple bioactive compounds rather than by a single chemical substance.

In the present study, the latex extract of A. irafensis showed significant antioxidant activity as shown by the DPPH free radical scavenging assay. This result is in agreement with a previous study which reported that Aloe species such as A. vera and A. inermis possessed high DPPH free-radical and superoxide-radical scavenging activities $[10,23]$.

In addition, the results of the present investigation clearly indicated the wound-healing properties of $A$. irafensis. A wound is the result of loss or damage of cellular, anatomical, or functional continuity of living tissues [24], whereas wound healing is the process of repairing injured tissues. Wound healing is considered effective if the wound is healed in a relatively short time with minimal pain, discomfort, and scarring $[25,26]$. The wound-healing process occurs in three phases: Inflammatory phase (hemostasis and inflammation), proliferative phase (granulation, contraction, and epithelialization), and remodeling phase, which organizes the newly-formed structures forming progressively increased tensile strength [25].

The findings of the present study confirmed the significant acceleration of dermal wound healing in rats following the topical twice-daily application of $A$. irafensis latex extract. The results of the present study are consistent with the previous studies that reported a significant wound healing activity of $A$. vera $[27,28]$. 


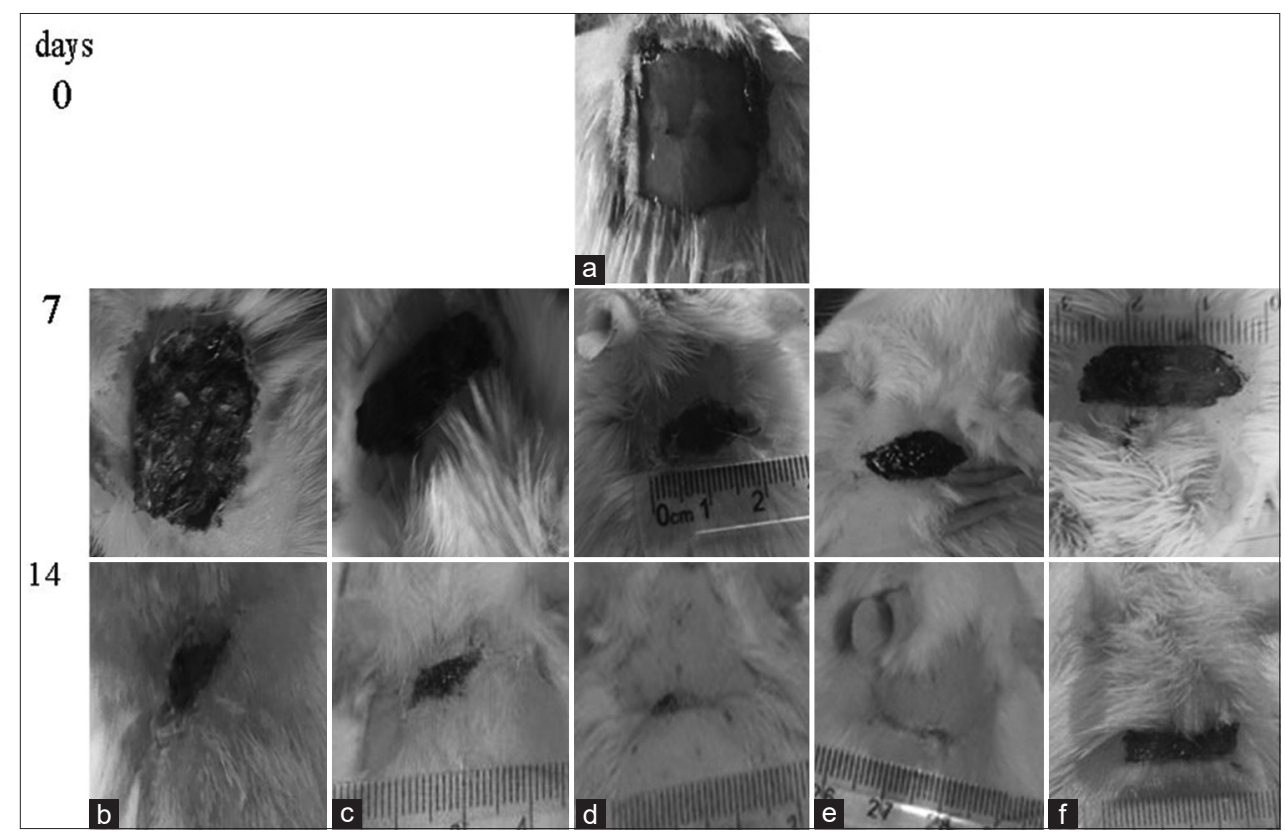

Fig. 4: Macroscopic appearance of wounds at days 0 (a) after surgery; (b): Untreated rats; (c) rats treated with $0.2 \mathrm{~mL}$ normal gum acacia (vehicle); (d) rats treated with $100 \mathrm{mg} / \mathrm{ml}$ of Aloe irafensis; (e) rats treated with $200 \mathrm{mg} / \mathrm{mL}$ of $A$. irafensis; (f) rats treated with fucidin ointment (positive control) at days 7 and 14

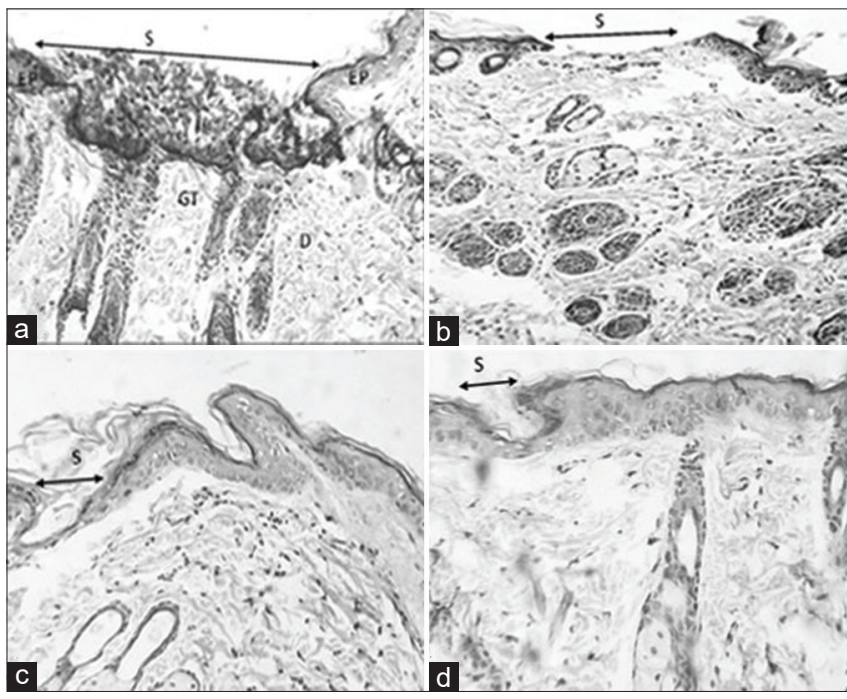

Fig. 5: Histological section of the 14-day-old granulation tissue of healed wound in: (a) Animals treated with vehicle, showing wide scar area (arrow) and not fully epithelialized, dense collagen fibers, fibroblasts with inflammatory cells showing incomplete healing, and showing focal ulceration of epidermis; (b) animals treated with Aloe irafensis $100 \mathrm{mg} / \mathrm{ml}$ showing a wide scar (arrow) area; (c) animals treated with A. irafensis $200 \mathrm{mg} / \mathrm{ml}$ showing a narrow scar (arrow) at the wound closure; (d) animals treated with fucidin showing a narrow scar area at the wound closure (arrow), $\mathrm{S}=\mathrm{scab}, \mathrm{EP}=$ epidermis, $\mathrm{D}=$ dermis and GT = granulation tissue ( $\mathrm{H}$ and $\mathrm{E} 400 \times)$

In the current study, the histopathological findings showed presence of collagen, fibroblasts, hair follicles, and blood capillaries in the granulation tissue of wounds treated with the latex extract. The wounds treated with the latex showed a proliferative phase and were associated with no presence of inflammatory cells. The proliferation of fibroblasts and production of collagen fibers were much greater in the latex-treated wounds compared to the vehicle group, indicating that the treated wounds had already gone through

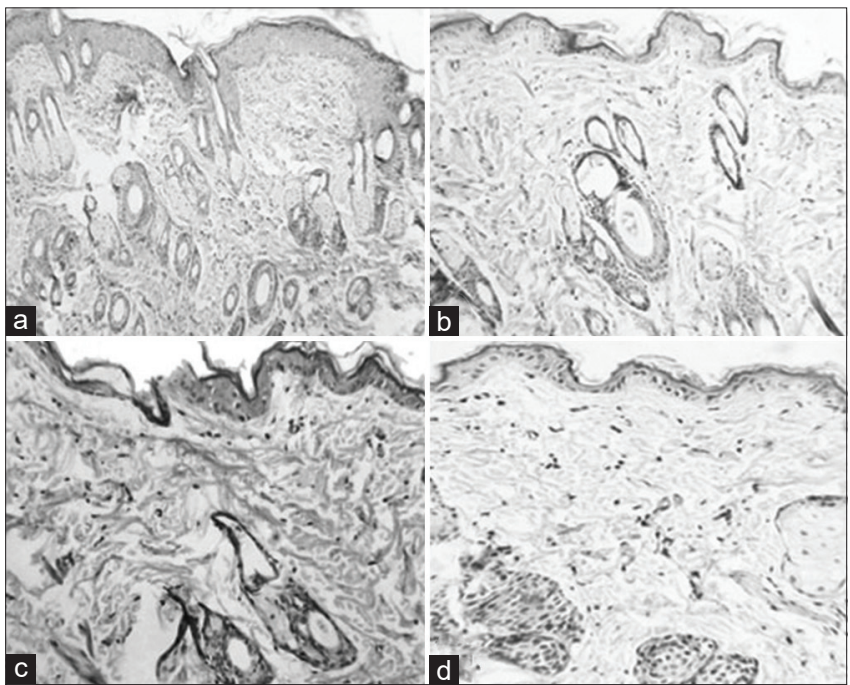

Fig. 6: Histological sections of the 14-day-old of healed tissue treatment with control, standard and test groups. (a) Granulation tissue of control group (vehicle) showing less collagen and abundent macrophages. $(b, c)$ Granulation tissue of extract treated group animals showing well-organized collagen bundles with and well-developed blood vessels. There were dense collagen fibers and fibroblasts with neovascularization and few macrophages.

(d) Granulation tissue of standard ointment (fucidin) treated group animal showing moderate deposition of collagen.

Appearance of skin appendages can also be visualized on 14 day of the experiment ( $\mathrm{H}$ and $\mathrm{E}$ stain, 200x)

the inflammatory phase and then entered the maturational phase. The anti-inflammatory activity of $A$. irafensis probably played a significant role in speeding the wound healing process by alleviating and shortening the early inflammatory phase post wounding [29]. In accordance, $A$. vera has also been shown to accelerate healing of burnt skin in rats by reducing inflammation and stimulating mature granulation tissue formation $[27,28]$. It is believed that rapid cellular proliferation, collagen deposition, epithelialization, myofibroblasts 
Table 3: Effect of latex extract of $A$. irafensis on the wound closure area in experimental rats

\begin{tabular}{|c|c|c|c|c|c|}
\hline \multirow[t]{3}{*}{ Day } & \multicolumn{5}{|c|}{ Wound area $\mathrm{mm}^{2}$ ( $\%$ wound healing) } \\
\hline & \multirow[t]{2}{*}{ Untreated } & \multirow[t]{2}{*}{ Gum acacia } & \multicolumn{2}{|l|}{ A. irafensis } & \multirow[t]{2}{*}{ Fusidin } \\
\hline & & & $100 \mathrm{mg} / \mathrm{ml}$ & $200 \mathrm{mg} / \mathrm{ml}$ & \\
\hline 0 & 4.0 & $4.0 \pm 0.5$ & $4.0 \pm 0.0$ & $4.0 \pm 0.6$ & $4.0 \pm 0.7$ \\
\hline 7 & $3.12 \pm 0.6(22.1)$ & $2.19 \pm 0.2^{2 * *}(45.2)$ & $1.6 \pm 0.3^{\mathrm{ab} * *}(60.1)$ & $0.93 \pm 0.2^{\mathrm{ab} * * * c *}(76.7)$ & $1.68 \pm 0.5^{\mathrm{ab} *}(58.1)$ \\
\hline 14 & $0.82 \pm 0.2(79.5)$ & $0.31 \pm 0.11^{\mathrm{a} * *}(92.4)$ & $0.03 \pm 0.02^{\mathrm{ab} * * * c *}(99.3)$ & $0.01 \pm 0.01^{\mathrm{ac} * * * \mathrm{~b} * *}(99.7)$ & $0.44 \pm 0.1^{\mathrm{a} * *}(89.0)$ \\
\hline
\end{tabular}

$\mathrm{WC} \%=$ percentage of wound closure. Data represent mean values $\pm \mathrm{SD}, \mathrm{n}=6,{ }^{\mathrm{a}}=$ significance compared to the untreated groups; ${ }^{\mathrm{b}}=$ significance compared to the gum acacia group; ${ }^{\mathrm{c}}=$ significance compared to the fusidic acid group, paired t-test; ${ }^{*} \mathrm{p}<0.05,{ }^{* *} \mathrm{p}<0.01,{ }^{* * *} \mathrm{p}<0.001$ was considered significant. A. irafensis: Aloe irafensis

production, and angiogenesis in and around the wounded area play major roles in wound healing [30].

Factors such as presence of microbes and free radicals can delay wound healing. Therefore, agents with antioxidant and antimicrobial activities could be helpful in accelerating wound healing [31,32]. Interestingly, the present study confirmed that the latex of $A$. irafensis possessed both antibacterial and antioxidant activities. It has been reported that flavonoids, saponins, tannins, and phenolic bioactive compounds promoted wound healing due to their antimicrobial and astringent properties [33,34]. Other studies reported that tannins promoted wound healing through scavenging free radicals and oxygen reactive species, promoting contraction of the wound and stimulating angiogenesis $[35,36]$. The current study showed the presence of several bioactive phytochemicals in A. irafensis (carbohydrates, steroids, phenols, tannins, and anthrones) which may be responsible for the shown latex wound healing effect.

\section{CONCLUSION}

In this study, the phytochemical analysis revealed that $A$. irafensis extracts contained various bioactive compounds. The study also showed that $A$. irafensis latex extract exhibited strong antibacterial, antioxidant, and wound-healing activity. The wound-healing activity of the plant extract was apparently achieved through promoting epithelialization, collagenation, neovascularization and by exhibiting antibacterial, antioxidant effects. The findings provide insight into the potential utilization of A. irafensis in the treatment of wounds, particularly those associated with bacterial infections. For such future applications, pinpointing and isolating the bioactive compounds responsible for the medicinal activities of $A$. irafensis are warranted.

\section{ACKNOWLEDGMENT}

The authors would like to thank the Microbiology Department of Yemen Lab, Sana`a Yemen; Yemen Standardization Metrology and Quality Control Organization, Sana`a, Yemen; Faculty of Pharmacy, Sana'a University, Yemen; Biology department, College of Science, King Khalid University, Saudi Arabia. Authors also wish to thank Dr. Abdul Wali Al Khulaidi, Public Authority for Research and Agricultural Extension, Dhamar, Yemen. Authors are grateful to Dr. Amin A. A-Doaiss, of the department of Anatomy and Histology, Faculty of Medicine, Sana'a University, Yemen, for his histological study.

\section{AUTHORS' CONTRIBUTIONS}

Dr. Bushra Abdulkarim Moharram and Dr. Hassan M. AL-Mahbashi conceived, designed and performed the experiments. Dr. Bushra Abdulkarim Moharram, Dr. Riyadh Saifali and Tareq Al-Maqtari analyzed the data and wrote the paper. All authors read and approved the final manuscript.

\section{CONFLICTS OF INTEREST}

There were no conflicts of interest.

\section{FUND}

This research did not receive any specific grant from funding agencies in the public, commercial, or not-for-profit sector.

\section{REFERENCES}

1. Cock I. The genus Aloe: Phytochemistry and therapeutic uses including treatments for gastrointestinal conditions and chronic inflammation. In: Rainsford K, Powanda M, Whitehouse M, editors. Novel Natural Products: Therapeutic Effects in Pain, Arthritis and Gastro-intestinal Diseases. New York: Springer; 2015. p. 179-235.

2. Tom R. The genus Aloe. Medicinal and aromatic plants industrial profiles. Boca Raton: CRC Press; 2004.

3. Al-Khulaidi A. Flora of Yemen. Sana'a, Yemen: (SEMP, YEM/97/100) EPC; 2013.

4. El-Shemy H, Aboul-Soud M, Nassr-Allah A, Aboul-Enein K, Kabash A, Yagi A. Antitumor properties and modulation of antioxidant enzymes' activity by Aloe vera leaf active principles isolated via supercritical carbon dioxide extraction. Curr Med Chem 2010;17:129-38.

5. Sharma B, Siddiqui S, Ram G, Chaudhary M, Sharma G. Hypoglycemic and hepatoprotective effects of processed Aloe vera gel in a mice model of alloxan induced diabetes mellitus. J Diabetes Metab 2013;4:1-6.

6. Nejatzadeh-Barandozi F. Antibacterial activities and antioxidant capacity of Aloe vera. Org Med Chem Lett 2013;3:5.

7. Zakieh K, Taha MR, Mehran V, Mohammad ZH, Haghighi HN, Mostafa I, et al. The effects of aqueous extract of Aloe vera leaves on the gastric acid secretion and brain and intestinal water content following acetic acid-induced gastric ulcer in male rats. Avicenna J Phytomed 2014;4:137.

8. Zandi K, Zadeh MA, Sartavi K, Rastian Z. Antiviral activity of Aloe vera against herpes simplex virus Type 2: An in vitro study. Afr J Biotechnol 2007;6:15.

9. Hamman JH. Composition and applications of Aloe vera leaf gel. Molecules 2008;13:1599-616.

10. Moharram BA, Al-Mahbashi HM, Al-Maqtari T, Al-Doaiss AA. Phytochemical, antibacterial, antioxidant and wound healing properties of Aloe inermislatex extract obtained from Yemen. Asian J Pharm Pharmacol 2019;5:1191-201.

11. Banu KS, Cathrine L. General techniques involved in phytochemical analysis. Int J Adv Res Comput Sci 2015;2:25-32.

12. Wagner H, Bladt S. Plant Drug Analysis: A Thin Layer Chromatography Atlas. Berlin: Springer Science and Business Media; 1996.

13. Moharram BA, Al-Mahbashi HM, Ali RS, Aqlan FA. Phytochemical, anti-inflammatory, antioxidant, cytotoxic and antibacterial study of Capparis cartilaginea decne from Yemen. Int J Appl Biol Pharm 2018;10:7.

14. Chiang HM, Lin YT, Hsiao PL, Su YH, Tsao HT, Wen KC. Determination of marked components aloin and aloe-emodin in Aloe vera before and after hydrolysis. J Food Drug Anal 2012;20:646-52.

15. Cavalieri SJ. Manual of Antimicrobial Susceptibility Testing. Washington DC, USA: American Society for Microbiology; 2005.

16. Jantan Ib, Karim Moharam BA, Santhanam J, Jamal JA. Correlation between chemical composition and antifungal activity of the essential oils of eight Cinnamomum species. Pharm Biol 2008;46:406-12.

17. Tsala DE, Amadou D, Habtemariam S. Natural wound healing and bioactive natural products. Phytopharmacology 2013;4:532-60.

18. Suvarna KS, Layton C, Bancroft JD. Bancroft's Theory and Practice of Histological Techniques. $7^{\text {th }}$ ed. London, UK: Churchill Livingstone; 2012.

19. Mukherjee PK, Nema NK, Maity N, Mukherjee K, Harwansh RK. Phytochemical and therapeutic profile of Aloe vera. J Nat Remedies 2013;14:1-26.

20. Thu K, Mon YY, Khaing TA, Tun OM. Study on phytochemical properties, antibacterial activity and cytotoxicity of Aloe vera L. World Acad Sci Eng Technol 2013;7:114-8.

21. Doss A, Mubarack HM, Dhanabalan R. Antibacterial activity of tannins from the leaves of Solanum trilobatum Linn. Indian J Sci Technol 
2009;2:41-3

22. Bradford PG, Awad AB. Phytosterols as anticancer compounds. Mol Nutr Food Res 2007;51:161-70.

23. Saritha V. Antioxidant and antibacterial activity of Aloe vera gel extracts. Int J Pharm Biol Arch 2010;1:376-84

24. Fulzele S, Satturwar P, Joshi S, Dorle A. Wound healing activity of Hingvadya Ghrita in rats. Indian Drugs 2002;39:606-9.

25. Singh S, Singh R, Kumar N, Kumar R. Wound healing activity of ethanolic extract of Plantago Ovata (Ispaghula) seeds. J Appl Pharm Sci 2011;1:18

26. Alam G, Singh MP, Singh A. Wound healing potential of some medicinal plants. Int J Pharm Sci Rev Res 2011;9:136-45.

27. Hamid AA, Soliman MF. Effect of topical Aloe vera on the process of healing of full-thickness skin burn: A histological and immunohistochemical study. J Histol Histopathol 2015;2:3.

28. Takzare N, Hosseini MJ, Hasanzadeh G, Mortazavi H, Takzare A, Habibi P. Influence of Aloe vera gel on dermal wound healing process in rat. Toxicol Mech Methods 2009;19:73-7.

29. Rezaie A, Najafzadeh H, Poormahdi-Broojeni M, Mohammadian B, Heidari M. Effects of Echinacea Purpura on wound healing after arsenic induced skin necrosis. Zahedan J Res Med Sci 2013;15:19-23.

30. Sarkar M, Das G, Pathak SK, Maitra S, Samanta A. Evaluation of in vivo wound healing and in vitro antibacterial activities of the different extract of Leucas indica Linn. Int J Pharm Pharm Sci 2013;5:333-40.

31. Lopes GC, Sanches AC, Nakamura CV, Dias Filho BP, Hernandes L, de Mello JC. Influence of extracts of Stryphnodendron polyphyllum Mart. and Stryphnodendron obovatum Benth. on the cicatrisation of cutaneous wounds in rats. J Ethnopharmacol 2005;99:265-72.

32. Sasidharan S, Nilawatyi R, Xavier R, Latha LY, Amala R. Wound healing potential of Elaeis guineensis Jacq leaves in an infected albino rat model. Molecules 2010;15:3186-99.

33. Ilodigwe E, Ndunagu L, Ajaghaku D, Utoh-Nedosa U. Evaluation of the wound healing activity of a polyherbal remedy. Ann Biol Res 2012;3:5393-8.

34. Kommu S, Gowrishankar NL, Kamala D, Saritha B, Srinivasulu V, Naresh B, et al. Evaluation of wound healing activity of methanolic extract of Balanites aegyptiaca L. leaves. Int J Pharm Pharm Sci 2013;5:52-3

35. Deters A, Dauer A, Schnetz E, Fartasch M, Hensel A. High molecular compounds (polysaccharides and proanthocyanidins) from Hamamelis virginiana bark: Influence on human skin keratinocyte proliferation and differentiation and influence on irritated skin. Phytochemistry 2001:58:949-58.

36. Fernandez O, Capdevila J, Dalla G, Melchor G. Efficacy of Rhizophora mangle aqueous bark extract in the healing of open surgical wounds. Fitoterapia 2002;73:564-8 